\title{
Strategi Pengembangan Kawasan Wisata Pasar Terapung Berbasis Kearifan Lokal di Kota Banjarmasin
}

\author{
Desy Sugianti \\ Program Pascasarjana Institut Seni Indonesia Yogyakarta \\ desysugi@gmail.com \\ Shellyana Junaedi \\ shellyjoen@gmail.com
}

\begin{abstract}
Abstrak
Banjarmasin dalam dunia kepariwisataan di Indonesia terkenal dengan kota seribu sungai. Sebagai salah satu daerah di Indonesia yang memiliki aliran sungai terbanyak membuat Banjarmasin juga dikenal sebagai kota dengan daya tarik pasar terapungnya. Di Kota Banjarmasin, pasar terapung yang dikenal luas oleh masyarakat dan sempat menjadi tema dari jargon salah satu televisi swasta di Indonesia adalah keberadaan Pasar Terapung Kuin. Seiring perkembangan zaman, kondisi Pasar Terapung Kuin saat ini mengalami kemunduran perkembangan. Banyak media baik online maupun surat kabar terbitan memberitakan tentang sepinya pembeli dan menurunnya jumlah pedagang yang berjualan di Pasar Terapung Kuin. Hal tersebut dikonfirmasi pula oleh beberapa pedagang yang tetap berjualan di Kuin. Melihat dari permasalahan tersebut kemudian pemerintah setempat melakukan tindakan guna menghidupkan kembali budaya sungai yang melekat erat sebagai image Kota Banjarmasin dengan membangun pasar terapung yang berada tepat berseberangan dengan titik 0 (nol) kilometer Kota Banjarmasin serta beberapa atraksi wisata lain di sekitar pasar terapung tersebut. Namun, sejak kehadiran Pasar Terapung Siring, jumlah kunjungan yang didata oleh pengelola menunjukkan adanya kesenjangan angka. Dimana Pasar Terapung Siring mampu mendatangkan tamu dengan angka mencapai sekitar 56.000-an (lima puluh enaman ribu), sementara kawasan Pasar Terapung Kuin hanya mampu menempati angka tertinggi dalam 1 tahun sebesar 3.000-an (tiga ribuan) pengunjung. Maka berdasarkan paparan tersebut dalam penelitian ini dilakukan pendekatan dengan metode penelitian triangulasi, menggunakan analisis kualitatif deskriptif dan analisis SWOT yang bertujuan untuk mengidentifikasi pengelolaan kawasan Pasar Terapung Kuin dan Siring untuk kemudian memformulasi strategi pengembangan kawasan pasar terapung di Banjarmasin. Dalam temuan penelitian berdasarkan hasil analisis kualitatif yang dilakukan, ditemukan bahwa; sistem pengelolaan terhadap Pasar Terapung Kuin dan Siring memiliki perbedaan yaitu; infrastruktur yang dikembangkan lebih banyak dilakukan di Siring, peran serta masyarakat yang terlibat dalam mengelola kepariwisataan pasar terapung juga lebih terorganisir di Siring. Sementara untuk kawasan Kuin belum adanya organisasi atau asosiasi resmi yang dibentuk oleh warga sekitar guna menjalankan program pengelolaan dan pengembangan kawasan dalam usaha untuk menghidupkan kembali budaya sungai di Banjarmasin. Arahan strategi berdasarkan analisis SWOT adalah kawasan wisata pasar terapung di Banjarmasin idelanya memiliki strategi dalam hal penambahan produk, pasar dan fungsi-fungsi kawasan serta melakukan pemanfaatan kekuatan dan peluang yang dimiliki. Strategi pengembangan terhadap kawasan pasar terapung di Banjarmasin mampu dikembangkan dan dapat menjalankan strategi yang bersifat ofensif.
\end{abstract}

Kata kunci: pasar terapung, pengelolaan, pengembangan kawasan, Banjarmasin. 


\begin{abstract}
Banjarmasin in the world of tourism in Indonesia known as the city of a thousand rivers. Banjarmasin is one of the areas in Indonesia that has the most river flow so that makes Banjarmasin also known as a city who has Floating Market. In the city of Banjarmasin, Floating Market (Kuin Floting market) widely known by the public after appeared in one of television in Indonesia as their theme of television slogan. Currently, Kuin floating market condition is on a decline in development. Many media such as online and newspaper published preach about the less of buyers and the declining number of traders who sell in Kuin Floating Market. It is also confirmed by some traders who keep selling in Kuin. Based on that case then the local government taken the action to revive the culture of the embedded river as the image of Banjarmasin City by builded a floating market that is near to the center of the city and became a part of tourist attractions in Banjarmasin. However the number of visitors that recorded by the manager shown a gap between Kuin and Siring. Where Siring floating market can bring guests with numbers reaching 56.000 visitors but Kuin floating market area is only able to occupy the highest lift in 1 year of 3.000 visitors. So based on that case, this research approached with trianggulation research method, using descriptive qualitative analysis and SWOT analysis which aims to identify the management of Kuin and Siring floating market area and then make a formulation of the development strategy of Floating Market area in Banjarmasin. This research found that; the management system of Kuin and Siring floating market has the difference action; Many Infrastructure developed has done in Siring, the participation of communities involved in managing tourism of the floating market and makes Siring also more organized. However, Kuin area hasn't official organization or association formed by local people to run the program of management and development of the area in an effort to revive the river culture in Banjarmasin. Strategy directives based on SWOT analysis are; Floating market tourism area in Banjarmasin ideally has a strategy in terms of addition of products, markets and functions of the region by using their strengths and opportunities. Development strategy for floating market area in Banjarmasin could be able to develop and run the offensive strategy.

Keywords: floating market, management, area development, Banjarmasin.
\end{abstract}

\title{
Pendahuluan
}

Kota Banjarmasin secara administrasi pada akhir tahun 2016 masih masuk ke dalam wilayah provinsi Kalimantan Selatan. Provinsi ini sebagian besar memiliki struktur geologi tanah basah (alluvial) yang kemudian memunculkan potensi geografis berupa banyak sungai yang berpangkal di Pegunungan Meratus dan bermuara ke Laut Jawa dan Selat Makasar (BPS, 2015). Merujuk pada faktor geografis, banyak sungai di daerah Kalimantan Selatan khususnya di Kota Banjarmasin inilah yang selama beratus-ratus tahun kemudian menyatu dengan cara hidup dan kebiasaan masyarakat lokal. Sebagai salah satu hasil pertemuan antara masyarakat dengan lingkungan, sungai memunculkan sebuah budaya yang telah bertahan lama dan tetap terus dipertahankan hingga saat ini, salah satunya adalah budaya berjualan yang menjadi dasar atas pemenuhan kebutuhan pokok manusia yang dilakukan dengan menyesuaikan kondisi lingkungan sungai yaitu keberadaan pasar terapung.

Pasar terapung merupakan pasar yang berada dan seluruh aktivitasnya dilakukan di atas air dan terdapat di kawasan yang memiliki banyak sungai-sungai besar atau anak sungai dan danau dimana warga atau masyarakat lokal banyak melakukan aktivitas atau kegiatan sehariharinya di atas air. 
Pasar Terapung Muara Kuin merupakan salah satu pasar terapung yang didaulat sebagai pasar tertua dan dikenal sebagai penggerak perekonomian Kota Banjarmasin sejak dulu. Pasar terapung (dalam hal ini Pasar Terapung Kuin) bersumber dari data BPS 2014 masuk dalam data "obyek wisata di Kota Banjarmasin" dan tidak berada di dalam data "nama pasar yang terdaftar di pemerintahan Kota Banjarmasin”. Sehingga, seiring perkembangannya Pasar Terapung Muara Kuin semakin dikenal sebagai sebuah kawasan wisata dan menjadi ikon kepariwisataan daerah yang masuk menjadi salah satu destinasi wisata menarik di Indonesia. Menyikapi pesatnya industri pariwisata, kemudian pemerintah daerah di tahun 2013 melakukan beberapa tindakan selain bertujuan untuk pelestarian kawasan pasar terapung, hal tersebut juga diindikasikan sebagai upaya dalam memajukan kepariwisataan daerah khususnya di Kota Banjarmasin sebagaimana yang dicantumkan dalam Pasal 2 dalam Peraturan Pemerintah Nomor 25 Tahun 2016. Salah satu tindakan yang saat itu telah dilakukan adalah menciptakan pasar terapung buatan yang letaknya berada di tengah kota dengan waktu akses pada siang hari menjelang malam, yaitu Pasar Terapung Sungai Siring.

Pasar Terapung Siring merupakan pasar terapung yang diupayakan pemerintah daerah untuk memberikan tambahan sajian atraksi pariwisata kepada wisatawan. Pasar terapung ini buka atau mulai beroperasi pada hari Sabtu pukul 16.00-19.00 WITA dan minggu pada 04.00-10.00 WITA. Selain itu, pemerintah setempat juga menghadirkan potensi destinasi baru melalui paket wisata susur sungai.

Destinasi wisata yang dimiliki Kota Banjarmasin sebagaimana yang telah dijelaskan sebelumnya, baik yang merupakan warisan sejarah ataupun yang dikembangakan sebagai pariwisata terkonsep kemudian ditemui data dalam bentuk angka. Angka berikut menunjukkan indikator kesuksesan pariwisata yang dimiliki Kota Banjarmasin saat ini, dalam laporan tamu angkutan objek wisata sungai yang dikelola oleh komunitas klotok angkutan objek wisata "Karya Bersama" Kota Banjarmasin yang bertempat di kawasan Siring Piere Tendean.

Tabel 1. 1. Laporan jumlah kunjungan tamu pasar terapung di Banjarmasin oleh organisasi kelotok wisata "Karya Bersama"

\begin{tabular}{|l|c|c|c|c|}
\hline \multicolumn{1}{|c|}{ Bulan, tahun } & $\begin{array}{c}\text { Tamu hari Sabtu- } \\
\text { Minggu, Jalan- } \\
\text { jalan @ Rp 5.000 }\end{array}$ & $\begin{array}{c}\text { Tujuan Pasar } \\
\text { Terapung } \\
\text { Kuin }\end{array}$ & $\begin{array}{c}\text { Susur Sungai } \\
\text { Keliling kota } \\
\text { Banjarmasin }\end{array}$ & $\begin{array}{c}\text { Total } \\
\text { Penumpang }\end{array}$ \\
\hline Januari 2016 & 27.143 & 900 & 301 & 28.344 \\
\hline Februari 2016 & 29.829 & 1.881 & 806 & 32.516 \\
\hline Maret 2016 & 32.242 & 2.004 & 258 & 34.504 \\
\hline April 2016 & 20.050 & 972 & 320 & 21.342 \\
\hline Mei 2016 & 31.312 & 3.155 & 641 & 35.108 \\
\hline Juni 2016 & 6.614 & 89 & 71 & 6.774 \\
\hline Juli 2016 & 32.873 & 2.938 & 487 & 36.298 \\
\hline Agustus 2016 & 31.430 & 1.442 & 204 & 33.076 \\
\hline September 2016 & 29.058 & 621 & 170 & 29.849 \\
\hline Oktober 2016 & 27.257 & 1034 & 162 & 28.453 \\
\hline November 2016 & 12.600 & 1400 & 621 & 14.621 \\
\hline Desember 2016 & 31.097 & 1076 & 292 & 32.465 \\
\hline Januari 2017 & 56.689 & 2274 & 284 & 59.247 \\
\hline Februari 2017 & 19.908 & 1360 & 210 & 21.478 \\
\hline Maret 2017 & 25.009 & 1221 & 532 & - \\
\hline April 2017 & - & - & - & 26.762 \\
\hline
\end{tabular}


Dari data yang tersaji pada tabel 1.1, angka indikator kunjungan tamu pada hari Sabtu dan Minggu untuk kawasan Siring Piere Tendean tertinggi berada pada bulan Januari 2017 dimana jumlah kunjungan mencapai angka 56.689 orang. Sedangkan untuk tamu dengan tujuan Pasar Terapung Kuin tertinggi berada pada bulan Mei 2016 yang hanya dapat mencapai angka 3.155 pengunjung. Hal ini menunjukkan terjadinya kesenjangan jumlah kunjungan terhadap 2 lokasi pasar terapung yang ada di wilayah Kota Banjarmasin. Kesenjangan tersebut menunjukan bahwa Pasar Terapung Kuin mengalami minat kunjungan yang jauh di bawah angka kunjungan yang dapat dicapai Pasar Terapung Siring dalam 1 bulan tertinggi selama 1 tahun terakhir.

Apabila melihat lagi ke Peraturan Walikota Nomor 25 Tahun 2016 Pasal 2 bahwasanya, tujuan dari pengelolaan dan pengembangan wisata berbasis sungai adalah untuk meningkatkan jumlah kunjungan dan mampu menjadi sarana dalam membuka peluang usaha. Hal tersebut tentu dapat dijalankan oleh kawasan Pasar Terapung Siring yang memiliki potensi besar dengan jumlah kunjungan yang telah disebutkan sebelumnya. Namun, bagaimana dengan Pasar Terapung Kuin yang jumlah kunjungan dalam 1 bulan di tahun 2016 tertinggi hanya mampu mencapai angka 3.155 tamu/pengunjung padahal waktu kunjungan atau akses ke kawasan dapat dilakukan setiap hari.

\section{Pertanyaan Penelitian}

- Bagaimana bentuk kearifan lokal masyarakat dalam pengelolaan kawasan pasar terapung di Banjarmasin?

- Bagaimana strategi pengembangan kawasan wisata Pasar Terapung di Banjarmasin yang berbasis kearifan lokal?

\section{Tujuan Penelitian}

1. Mengidentifikasi bentuk kearifan lokal masyarakat dalam pengelolaan kawasan wisata Pasar Terapung Kuin dan Pasar Terapung Siring di Kota Banjarmasin.

2. Mengeksplorasi, menganalisis, dan memformulasikan strategi dalam pengembangan kawasan wisata pasar terapung Kota Banjarmasin yang berbasis kearifan lokal.

\section{Metode Penelitian}

Dalam penelitian ini metode yang digunakan yaitu triangulasi kualitatif deskriptif dengan kuantitatif analisis SWOT. Dengan melakukan pengumpulan data berupa wawancara (indepth interview) yang bersifat semi terstruktur. Adapun teknik sampling yang digunakan yaitu teknik purposive sampling, dimana pemilihan sampel dipilih secara sengaja dan dengan tujuan tertentu. Kemudian analisis data dilakukan dengan metode analisis isi dan diteruskan dengan analisis SWOT untuk mendapatkan formulasi strategi pengembangan kawasan wisata Pasar Terapung di Banjarmasin.

1) Lokasi Penelitian

Penelitian ini dilakukan di Pasar Terapung di Kota Banjarmasin yang meliputi: Pasar Terapung Muara Kuin dan Pasar Terapung Siring serta destinasi potensial di sepanjang kawasan Siring Piere Tendean. Lokasi kawasan Pasar Terapung Muara Kuin berada di 
Kecamatan Banjarmasin Utara, Kota Banjarmasin, dan Pasar Terapung Sungai Siring berada di Jalan Kapten Tendean No. 20, Gadang, Banjarmasin Tengah, Kota Banjarmasin, Kalimantan Selatan.

\section{2) Objek Penelitian}

Penelitian dilakukan di pasar Terapung Muara Kuin Kelurahan Alalak Selatan dan Pasar Terapung Siring Jalan Piere Tendean di Kota Banjarmasin untuk memformulasi strategi pengembangan kawasan wisata Pasar Terapung di Banjarmasin yang berbasis kearifan lokal.

\section{3.) Subjek Penelitian}

Penetapan sampel atau subjek penelitian dalam metode penelitian kualitatif memiliki tujuan untuk memperdalam pemahaman tentang proses, hubungan, atau kejadian sosial yang lebih besar. Sampel memberi informasi berharga atau sejumlah aspek baru. Aspek-aspek tersebut menekankan, meningkatkan, atau memperkaya fitur atau situasi utama (Neuman, 2013). Dalam penelitian kualitatif, "relevansi terhadap topik penelitian, bukannya keterwakilan mereka, yang menentukan cara penilihan orang yang akan diteliti”. (Flick, 1998:41 dalam Neuman, 2013).

\section{Teknik Pengumpulan Data}

Pada bagian ini, data dikumpulkan dari data primer dan data sekunder. Data primer terdiri dari:

1) Identifikasi

Dalam hal ini peneliti melakukan proses identifikasi terhadap pengelolaan Kawasan Wisata Pasar Terapung Siring dan Kuin.

2) Wawancara/pertanyaan terbuka

Beberapa pertanyaan akan diajukan kepada subjek penelitian terkait hasil pengamatan, data subjek penelitian tersaji pada table 3. 1. Subjek/informan adalah ahli atau mengerti mengenai strategi kawasan Pasar Terapung Siring dan di Kota Banjarmasin sehingga informasi yang diperoleh dapat dipertanggungjawabkan. Wawancara berupa in-depht interview yang bersifat terbuka yaitu memungkinkan untuk peneliti memperluas jangkauan pertanyaan, dan semi terstruktur yaitu tidak terlalu terpaku pada struktur pertanyaan wawancara.

Tabel 3.2. Proses Pengumpulan Data

\begin{tabular}{|l|l|c|}
\hline Durasi Wawancara & \multicolumn{1}{|c|}{ Nama Informan } & Keterangan Tempat \\
\hline 25.00 menit & $\begin{array}{l}\text { M. Khuzaimi (Kabid pengembangan dinas } \\
\text { Pariwisata). }\end{array}$ & Kantor Dinas Pariwisata \\
\hline 25.00 menit & $\begin{array}{l}\text { Koordinator dermaga wisata Siring Piere } \\
\text { Tendean }\end{array}$ & Menara Pandang Siring \\
\hline 09.00 menit & $\begin{array}{l}\text { Koordinator pedagang pasar terapung } \\
\text { Siring }\end{array}$ & Rumah Lanting Siring \\
\hline 10.00 menit & Ibu Wahida & Kediaman Pribadi Pedagang \\
\hline 08.00 menit & Ibu Nuriyah & Pasar Terapung Siring \\
\hline 1 jam 12 menit & Bapak Rahman & Area Tempat Makan \\
\hline 10 menit & Ibu Hj. Saonah & Area Kampus ULM \\
\hline 10 menit & Ibu Junaina & \\
\hline 08.00 menit & Evie Rizkie Yulita (Perempuan, 26 tahun) & \\
\hline 25.00 menit & Nia Laraswati (Perempuan, 19 tahun) & \\
\hline
\end{tabular}




\section{3) Dokumentasi}

Data dokumentasi akan dikumpulkan melalui portrait lapangan berupa foto dengan menggunakan media kamera digital. Studi terhadap publikasi yang bersumber dari berbagai media cetak yang berkaitan dengan objek penelitian yaitu Pasar Terapung Muara Kuin dan Pasar Terapung Siring. Serta melakukan perekaman terhadap subjek penelitian yang dapat menunjang data peneliti.

\section{Variabel}

Pada penelitian ini, variabel yang digunakan kemudian diolah ke dalam faktor internal dan ekternal. Faktor internal memuat kekuatan dan kelemahan, sedangkan faktor eksternal memuat peluang dan ancaman. Variabel dijabarkan berdasarkan dari definisi kawasan wisata, dimana kawasan wisata atau disebut juga sebagai destinasi wisata dalam peraturan Undangundang No. 9 Tahun 2009 tentang kepariwisataan menyebutkan bahwa, destinasi pariwisata adalah kawasan geografis yang berada dalam satu atau lebih wilayah administratif yang di dalamnya terdapat daya tarik wisata, fasilitas umum, fasilitas pariwisata, aksesibilitas, serta masyarakat yang saling terkait dan melengkapi terwujudnya kepariwisataan.

\section{Hasil dan Pembahasan}

Berdasarkan hasil studi literatur, tinjauan lapangan, identifikasi, dan wawancara mendalam terhadap sistem pengelolaan kawasan Pasar Terapung Siring dan Kuin di Kota Banjarmasin, serta tahap identifikasi pengelolaan kawasan untuk dikembangkan ke dalam strategi pengembangan yang berkelanjutan, maka didapatkan hasil sebagai berikut:

\section{a. Pengelolaan Kawasan Pasar Terapung Kuin}

Sistem pengelolaan yang dilakukan atau dijalankan untuk Pasar Terapung Kuin lebih kepada berbasis masyarakat. Dalam hal pengembangan, Pemerintah Kota Banjarmasin sejauh ini masih memberikan sentuhan, dan belum tertata seperti di Pasar Terapung Tendean, pengelolaan di Pasar Terapung Kuin masih secara alami. Pemerintah setempat, terutama Dinas Pariwisata memberikan sejauh ini hanya memberikan stimulasi berupa pintu akses pengunjung yang dibuka untuk tujuan destinasi Pasar Terapung Kuin dari Pasar Tendean. Hal tersebut diharapkan dapat menghidupkan kembali geliat masyarakat dan Pasar Terapung Kuin.

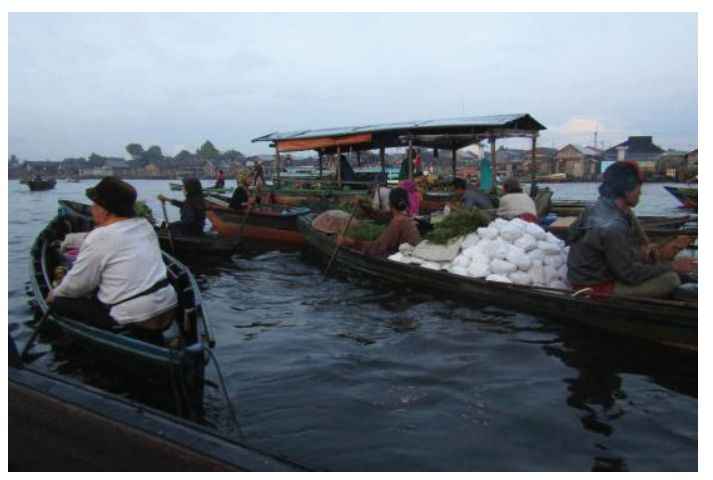




\section{- Daya tarik wisata}

Informan mengungkapkan terhadap variabel daya tarik wisata adalah untuk menjalankan visi dan misi pengelolaan terhadap kawasan Pasar Terapung Kuin guna penguatan identitas Kota Banjarmasin sebagai Kota Seribu Sungai sehingga peningkatan dalam hal transportasi sungai dapat terwujud. Dalam upaya pelaksanaan visi dan misi pengelolaan, atraksi wisata ditambahakan berupa susur sungai guna mendukung peningkatan kunjungan ke kawasan Pasar Terapung Kuin. Selain itu tujuan dibentuknya wisata susur sungai juga sebagai bentuk stimulus untuk mengaktifkan lagi geliat Pasar Terapung Kuin yang perlahan hilang. Selain itu juga terdapat program SIDA yang dirancang sebagai bentuk tindakan pelestarian kawasan Pasar Terapung Kuin.

\section{- Fasilitas umum}

Dalam pantauan peneliti, beberapa fasilitas umum belum disediakan di lokasi ini baik untuk para pengunjung dan wisatawan yang datang ataupun pedagang Pasar Kuin. Toilet-toilet yang ada adalah milik pribadi yaitu milik warga-warga yang bermukim disekitaran kawasan Pasar Terapung Kuin.

\section{- Fasilitas Pariwisata}

Dalam pantauan peneliti, adanya dermaga yang disediakan oleh masyarakat atau warga sekitar. Tetapi dalam catatan lapangan peneliti yang ditinjau pada tanggal 12 Februari 2017, di lokasi dermaga Pasar Terapung Kuin yang berada berdampingan dengan lokasi dermaga penyeberangan penumpang pukul 05.40, memperlihatkan kondisi di lapangan sepi pedagang yang dahulunya berkumpul di dermaga pada pagi hari saat itu sudah tidak ada. Menurut penuturan warga kawasan Kuin, pedagang telah bergeser ke utara disebabkan kawasan yang dahulunya adalah dermaga penyeberangan, saat ini telah berpindah lebih ke selatan dari posisi awalnya. Selain di dermaga inti ini, terdapat pula dermaga di sebrang masjid dan makan Sultan Suriansyah yang kurang lebih berjarak 1 kilometer, dan beberapa ditemukan pula di sepanjang jalan masuk menuju lokasi dermaga Pasar Terapung Kuin yang dikelola secara perorangan/pribadi oleh masyarakat setempat.

\section{- Aksesibilitas}

Lokasi pasar terapung Kuin dapat ditempuh melalui jalur darat dan disambung dengan menggunakan jalur sungai. Atau bisa pula pengunjung yang ingin menikmati suasana sungai di Kota Banjarmasin dapat menggunakan angkutan kelotok wisata yang disediakan pemerintah dengan dermaga yang berada di kawasn Siring Tendean yang terletak di pusat kota, tidak jauh dari titik $0 \mathrm{~km}$ kota Banjarmasin. Selain itu terdapat pula dermaga yang berada di kawasan Kuin, Alalak Selatan yang dibangun oleh warga sekitar. Yaitu dermaga di seberang Masjid Sultan Suriansyah, depan makan Sultan Suriansyah, dan didekat dermaga penyeberangan. Apabila dari pusat kota, area Pasar Terapung Kuin kurang lebih berjarak 7 kilometer. Selain melalui dermaga di kawasan Siring, terdapat beberapa pintu masuk wisatawan atau pengunjung untuk menuju kawasan ini. Terdapat satu buah bandara di Kalimantan Selatan yang berjarak kurang lebih 15 kilometer menuju pusat Kota Banjarmasin. Di Kota Banjarmasin sendiri terdapat pelabuhan yang berjarak 8 kilometer dari lokasi Pasar Terapung Kuin. Waktu akses untuk kawasan Pasar Terapung Kuin adalah pada waktu setelah subuh atau pukul 05.00 WITA hingga 09.00 WITA. 


\section{- Pedagang Kuin}

Pedagang mengaku bahwa pengelolaan di kawasan Pasar Terapung Kuin masih sangat tradisional, hal tersebut dibuktikan dengan tidak ada lembaga atau organisasi yang menaungi pedagang sehingga untuk mengantisipasi pengurangan jumlah pedagang yang berjualan di Pasar Terapung Kuin tidak dilakukan. Beberapa upaya yang diutarakan oleh salah seorang narasumber pedagang Pasar Terapung Kuin bahwa upaya pelestarian atau pengembangan kawasan sejauh ini dilakukan oleh pemerintah setempat melalui pemberian bantuan sarana berjualan, seperti perbaikan dan pemberian jukung (perahu) dan pemberian dana sebagai bentuk stimulasi untuk pedagang agar tetap mau dan bertahan untuk berjualan di kawasan Pasar Terapung Kuin. Selain itu, pembangunan dermaga di kawasan Kuin juga dilakukan sebagai bentuk tambahan fasilitas wisata untuk kawasan tersebut.

\section{- Pengunjung Kuin}

Simpulan dari respon informan terhadap pertanyaan yang diajukan adalah bahwa informan menganggap kondisi alam dan budaya berjualan di atas air merupakan daya tarik yang dimiliki kawasan Pasar Terapung Kuin. Dalam hal fasilitas wisata yang ditangkap dari pengamatan pengunjung di lokasi Pasar Terapung Kuin adalah tersedianya tukang parkir untuk mengamankan kendaraan milik pengunjung. Dari sisi fasilitas umum, sepenangkap informan yang ada di lokasi Pasar Terapung Kuin hanya tersedianya fasilitas tempat parkir. Sedangkan dari sisi aksesibilitas, informan lebih menyarankan menggunakan sepeda motor dibandingkan mobil karena akses menuju lokasi terbilang sulit. Dan dari segi masyarakat, informan memberikan nilai 'ramai' terhadap pelayanan penjual kepada pembeli di Pasar Terapung Kuin, kebersihan yang dijaga oleh masyarakat lokal, dan menyadari perannya untuk turut andil dalam pelestarian kawasan dengan cara menjaga kebersihan kawasan dan menyebarkan informasi kawasan Pasar Terapung Kuin kepada kolega terdekat dan masyarakat luas.

\section{b. Pengelolaan Kawasan Pasar Terapung Siring}

Pada tahun awal dimulainya keberadaan Pasar Terapung di kawasan Siring Piere Tendean berada tepat di seberang titik 0 (nol) kilometer Kota Banjarmasin atau berjarak sekitar 400 meter dari lokasi pasar terapung saat ini (tahun 2017). Menurut penuturan narasumber PGL1, alasan dipilihnya lokasi Pasar Terapung Siring tepat berada di titik 0 (nol) kilometer atau di tengah kota adalah untuk memberikan kemudahan akses bagi para wisatawan atau pengunjung yang ingin melihat, dan mengunjungi pasar terapung di Kota Banjarmasin yang telah lama dikenal identik dengan Kota Seribu Sungai dan Pasar Terapung sebagai ikon wisatanya. Dari pedagang Pasar Terapung Siring didominasi oleh pedangan dari Pasar Terapung Lok Baintan. Hal tersebut dikarenakan untuk pedagang pasar terapung di Kota Banjarmasin dinilai sudah sedikit jumlahnya dan minim regenerasi. Sehingga pengelola mendatangkan pedagang dari lokasi Lok Baintan. 


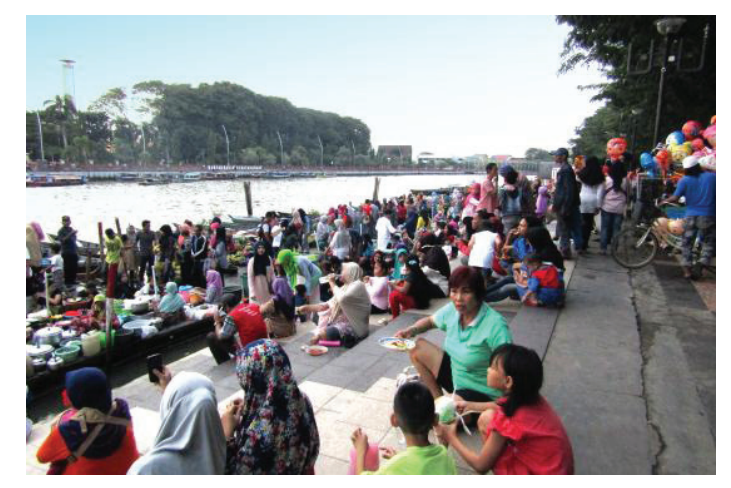

\section{- Daya Tarik Wisata}

Pasar Terapung Siring yang berada di Jalan Piere Tendean ini selain menyediakan atraksi wisata pasar terapung, kawasan ini juga memiliki beberapa alternatif destinasi lain untuk pengunjung atau wisatawan yang berada di kawasan Siring meliputi Patung Bekantan, menara susur sungai, dan menara pandang.

\section{- Fasilitas Umum}

Terdapat Toilet umum yang diletakan di sekitar area Siring Piere Tendean. Penuturan informan dan dari pengamatan peneliti di lapangan bahwa toilet wisata disediakan di seberang titik 0 (nol) kilometer Banjarmasin, area menara pandang, dan yang sedang dibangun berada di dekat Patung Bekantan. Untuk fasilitas ATM seperti yang diutarakan PGL2 masih belum ada.

\section{- Fasilitas Pariwisata}

Terdapat beberapa fasilitas penunjang pariwisata yang disediakan di sekitar kawasan Pasar Terapung Siring Piere Tendean. Fasilitas tersebut yaitu adanya area tempat makan yang banyak berada di belakang kawasan Patung Bekantan, yang paling nampak terlihat yaitu keberadaan Taher Squer. Tempat ini dibangun serupa foodcourt. Dimana terdapat banyak stand makanan yang mengitari area tersebut, kemudian disediakan tempat duduk ditengah-tengah area. Konsep tempat makan ini adalah open space. Pengunjung dapat menyantap makanan dan sekaligus menikmati pemandangan sungai di kawasan Siring Piere Tendean. Terdapat kurang lebih 40 stand makanan di area ini.

\section{- Aksesibilitas}

Untuk menuju ke lokasi Pasar Terapung Siring dinilai cukup mudah bagi para pengunjung ataupun wisatawan yang datang ke Banjarmasin. Karena letaknya yang strategi yaitu langsung berada di pusat kota. Hanya berjarak kurang lebih 5 kilometer dari gedung perkantoran pemerintah Kota Banjarmasin. Dan tepat berseberangan dengan lokasi titik 0 (nol) kilometer Kota Banjarmasin. Terdapat empat pintu masuk untuk wisatawan atau yang akan berkunjung ke Kota Banjarmasin, yaitu dengan tersedianya bandara internasional yang berjarak kurang lebih 20 kilometer dari pusat Kota Banjarmasin, terdapat Pelabuhan Trisakti yang berjarak kurang lebih 10 kilometer, adanya terminal "Km 6" untuk trayek antarkota dan antarprovinsi yang berjarak kurang lebih 10 kilometer dari pusat kota, serta akses jalan raya dengan kondisi jalan yang layak dilalui untuk menunjang akses darat dan beberapa disediakan pula akses sungai yang melayani rute dalam kota untuk tujuan pariwisata. 


\section{- Pedagang Siring}

Rata-rata pedagang di Pasar Terapung Siring merupakan pedagang yang berjualan di Pasar Terapung Lok Baintan Kabupaten Banjar. Namun ada pula yang berdagang di darat pada hari-hari biasa. Informan sebagai pedagang menuturkan bahwa pendapatan yang dihasilkan dari berdagang di Pasar Terapung Siring lebih dari yang didapat pada hari-hari biasa. Hal tersebut dikarenakan pengunjung yang datang ke kawasan Pasar Terapung Siring sangat banyak dan beragam dari berbagai daerah di Indonesia maupun masyarakat yang berdomisili di Kota Banjarmasin dan sekitarnya. Pada awal pembentukan pasar terapung Siring, pedagang mengaku dibekali dengan uang Rp 50.000,00 (lima puluh ribu rupiah) setiap kali berdagang di Siring oleh pemerintah setempat tetapi setelah terlaksana dengan sukses kawasan tersebut pemberian dana kemudian dihentikan.

\section{- Pengunjung Siring}

Informan merupakan pengunjung yang kerap datang ke kawasan Pasar Terapung Siring. Lokasi pasar terapung ini berjarak 3 jam dari kediamannya jika ditempuh dengan kendaraan bermotor. Informan mengaku ketertarikannya terhadap kawasan Pasar Terapung Siring adalah karena kuliner yang dijual. Selain itu, budaya berjualan di atas air juga menjadi ketertarikan dan alasan informan untuk terus berkunjung ke lokasi tersebut. Selain itu yang menarik minat informan terhadap kawasan Pasar Terapung Siring adalah wisata susur sungai-nya. Infroman mengungkapkan fasilitas keamanan yang baik di kawasan tersebut. Namun informan tidak melihat adanya toko souvenir yang berada di kawasan Pasar Terapung Siring. Untuk fasilitas toilet umum pun masih belum dapat ditemukan dengan mudah oleh informan. Informan mengungkapkan kemudahan akses menuju ke kawasan Pasar Terapung Siring.

\section{Analisis SWOT}

Tabel Matrik IE Pengembangan Kawasan Pasar terapung di Kota Banjarmasin berbasis kearifan local

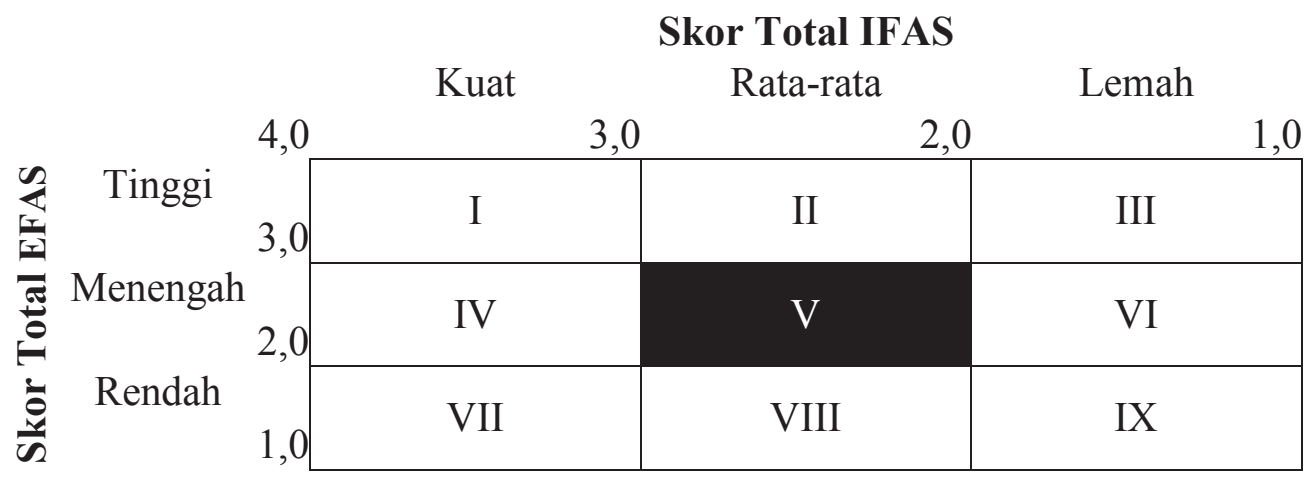

Berdasarkan hasil yang ditunjukkan pada Matriks IE tersebut, pengembangan kawasan wisata pasar terapung di Kota Banjarmasin berada pada posisi V. Hal tersebut menunjukkan bahwa strategi pengembangan kawasan wisata pasar terapung berada pada posisi penetrasi pasar dan pengembangan produk. Dengan melakukan pertahanan terhadap potensi-potensi yang dimiliki dan kemudian membina atau mengembangkannya. 
Kuadran analisis SWOT pengembangan kawasan wisata pasar terapung di Kota Banjarmasin menujukkan posisi di kuadran I.

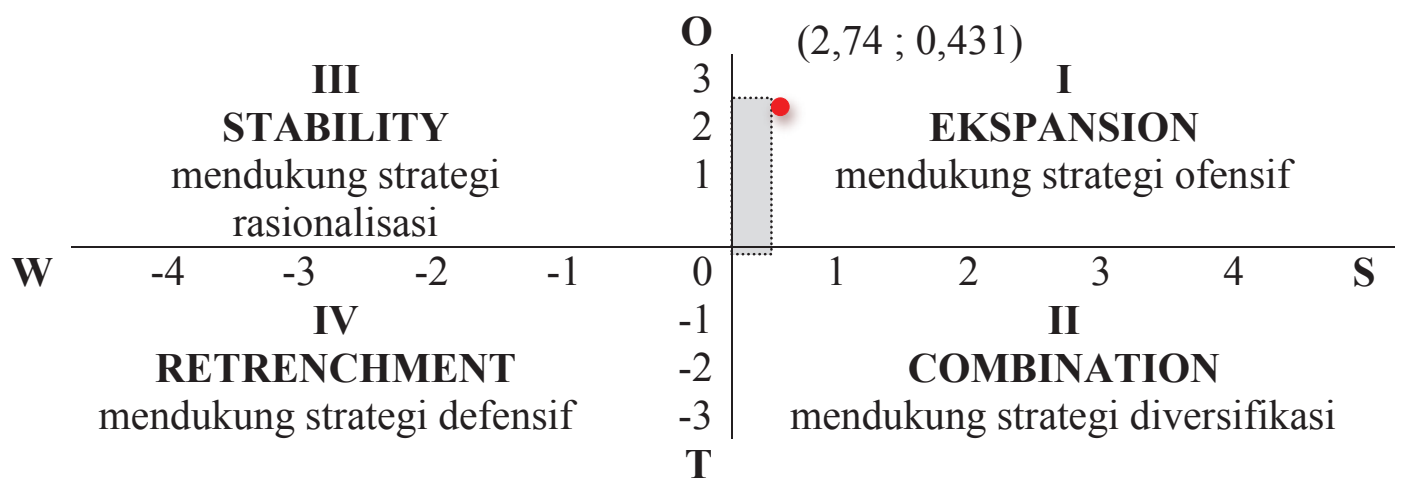

Hal ini memiliki artian bahwa pengelola kawasan wisata pasar terapung di Banjarmasin idealnya memiliki strategi dalam hal penambahan produk, pasar, dan fungsifungsi kawasan serta melakukan pemanfaatan kekuatan dan peluang yang dimiliki. Strategi yang harus diterapkan dalam kondisi ini adalah mendukung kebijakan pengembangan yang agresif. Dengan melakukan pemanfaatan dari sisi kekuatan serta peluang pariwisata yang tersedia sehingga mampu mereduksi sisi kelemahan dan ancaman yang dimiliki oleh kawasan wisata pasar terapung di Banjarmasin.

Dari hasil matrik SWOT, diperoleh kesimpulan strategi yang sebaiknya dilakukan dalam pengelolaan kawasan wisata Pasar Terapung Kota Banjarmasin sehingga mampu menjadi pariwisata berkelanjutan yang berbasis pariwisata kreatif yaitu sebagai berikut:

\begin{tabular}{|c|c|c|}
\hline & & \\
\hline EFAS & $\begin{array}{l}\text { Daya tarik sungai dengan } \\
\text { ragam atraksi } \\
2 \text { Pasar terapung di } \\
\text { Banjarmasin sebagai penguat } \\
\text { identitas budaya } \\
\text { Terbentuknya pelaku usaha } \\
\text { bidang kepariwisataan yang } \\
\text { beragam } \\
\text { Tersedianya fasilitas akomodasi } \\
\text { untuk wisatawan nasional dan } \\
\text { mancanegara } \\
\text { Daya tarik ragam kuliner lokal }\end{array}$ & $\begin{array}{l}\text { - } \text { Minim armada angkutan } \\
\text { umum/transportasi umum } \\
\text { Lemahnya fasilitas penguat } \\
\text { identitas wisata seperti toko } \\
\text { souvenir } \\
\text { - } \text { Sistem Informasi lemah } \\
\text { - Tidak ada fasilitas perbankan di } \\
\text { kawasan Pasar terapung } \\
\text { Minim fasilitas umum untuk } \\
\text { wisatawan }\end{array}$ \\
\hline Peluang (O) & Strategi & \\
\hline $\begin{array}{l}\text { Terbukanya jalur masuk } \\
\text { wisatawan nasional dan } \\
\text { internasional melalui fasilitas } \\
\text { Bandara } \\
\text { Tersedianya jalur antar kota } \\
\text { melalui akses jalan raya } \\
\text { Terbukanya jalur masuk antar } \\
\text { pulau melalui pelabuhan } \\
\text { Dapat menunjang masuknya } \\
\text { wisatawan antar provinsi melalui } \\
\text { akses terminal Bus } \\
\text { Tersedianya fasilitas layanan }\end{array}$ & $\begin{array}{l}\text { Daya tarik wisata yang dimiliki } \\
\text { kawasan pasar terapung di Kota } \\
\text { Banjarmasin, harus mampu } \\
\text { diimbangi dengan tambahan } \\
\text { infrastruktur serta fasilitas akses } \\
\text { kepariwisataan yang prima } \\
\text { sehingga mampu menjadikan } \\
\text { peluang dalam meningkatkan } \\
\text { kunjungan wisatawan ke Kota } \\
\text { Banjarmasin. } \\
\text { Fasilitas akomodasi dan } \\
\text { restorasi/kuliner yang memiliki }\end{array}$ & $\begin{array}{l}\text { Dengan telah tersedianya jalur } \\
\text { masuk pengunjung/wisatawan ke } \\
\text { Banjarmasin, sistem transportasi } \\
\text { umum harus mampu } \\
\text { mengimbangi jumlah kunjungan } \\
\text { tamu yang datang ke Kota } \\
\text { Banjarmasin. } \\
\text { Sebagai bentuk pelayanan } \\
\text { terhadap wisatawan, fasilitas } \\
\text { pariwisata mampu berkoordinasi } \\
\text { dengan transportasi umum yang } \\
\text { ada sehingga terdapat kemudahan }\end{array}$ \\
\hline
\end{tabular}




\begin{tabular}{|c|c|c|c|c|}
\hline $\begin{array}{l}\text { keamanan untuk wisatawan di } \\
\text { lokasi Pasar terapung }\end{array}$ & & $\begin{array}{l}\text { sistem keamanan optimal akan } \\
\text { membuat wisatawan yang telah } \\
\text { berkunjung ke Banjarmasin } \\
\text { dapat kembali mengunjungi } \\
\text { kota ini dikemudian hari. }\end{array}$ & 0 & $\begin{array}{l}\text { bagi wisatawan untuk mengakses } \\
\text { segala kebutuhannya selama } \\
\text { berwisata. } \\
\text { Peningkatan keamanan untuk } \\
\text { wisatawan dalam mengakses } \\
\text { fasilitas pariwisata. }\end{array}$ \\
\hline \begin{tabular}{l}
\multicolumn{1}{c}{ Ancaman (T) } \\
Perubahan struktur \\
kawasan/geografi \\
Dekonstruksi terhadap \\
interpretasi berbagai tradisi \\
Komuditasisasi yang memicu \\
konflik \\
Pendangkalan kualitas \\
disebabkan komersialisasi \\
budaya \\
Wisata sejenis di Indonesia
\end{tabular} & 0 & \begin{tabular}{l}
\multicolumn{1}{c}{ Strategi ST } \\
Memsosialisasi masyarakat \\
akan pentingnya peran warga \\
lokal dalam menjaga segala \\
potensi/daya tarik yang dimiliki \\
oleh Kota Banjarmasin. \\
Menciptakan kegiatan \\
kepariwisataan yang \\
berkelanjutan dalam \\
menghadapi pesatnya \\
kepariwisataan di Indonesia.
\end{tabular} & O & \begin{tabular}{l}
\multicolumn{1}{c}{ Strategi WT } \\
Menciptakan kesadaran di \\
masyarakat akan pentingnya \\
peran lokal dalam peningkatan \\
fasilitas transportasi. \\
Peningkatan ekonomi oleh \\
masyarakat lokal dalam \\
menciptakan produk-produk \\
pariwisata, serta dalam hal \\
pengembanagn destinasi wisata \\
yang mampu memberikan \\
pelayanan prima tidak hanya \\
kepada pengunjung/wisatawan \\
tetapi memberikan timbal balik \\
yang berpengaruh terhadap \\
keberlangsungan budaya, dan \\
tradisi lokal.
\end{tabular} \\
\hline
\end{tabular}

SO:

1. Daya tarik wisata yang dimiliki kawasan pasar terapung di Kota Banjarmasin, harus mampu diimbangi dengan tambahan infrastruktur serta fasilitas akses kepariwisataan yang prima sehingga mampu menjadikan peluang dalam meningkatkan kunjungan wisatawan ke Kota Banjarmasin.

2. Fasilitas akomodasi dan restorasi/kuliner yang memiliki sistem keamanan optimal akan membuat wisatawan yang telah berkunjung ke Banjarmasin dapat kembali mengunjungi kota ini di kemudian hari.

WO:

1. Dengan telah tersedianya jalur masuk pengunjung/wisatawan ke Banjarmasin, sistem transportasi umum harus mampu mengimbangi jumlah kunjungan tamu yang datang ke Kota Banjarmasin.

2. Sebagai bentuk pelayanan terhadap wisatawan, fasilitas pariwisata mampu berkoordinasi dengan transportasi umum yang ada sehingga terdapat kemudahan bagi wisatawan untuk mengakses segala kebutuhannya selama berwisata.

3. Peningkatan keamanan untuk wisatawan dalam mengakses fasilitas pariwisata.

ST:

1. Mensosialisasi masyarakat akan pentingnya peran warga lokal dalam menjaga segala potensi/daya tarik yang dimiliki oleh Kota Banjarmasin.

2. Menciptakan kegiatan kepariwisataan yang berkelanjutan dalam menghadapi pesatnya kepariwisataan di Indonesia.

\section{WT:}

1. Menciptakan kesadaran di masyarakat akan pentingnya peran lokal dalam peningkatan fasilitas transportasi.

2. Peningkatan ekonomi oleh masyarakat lokal dalam menciptakan produk-produk pariwisata, serta dalam hal pengembanagn destinasi wisata yang mampu memberikan 
pelayanan prima tidak hanya kepada pengunjung/wisatawan tetapi memberikan timbal balik yang berpengaruh terhadap keberlangsungan budaya, dan tradisi lokal.

\section{Kesimpulan}

Berdasarkan hasil penelitian, maka disimpulkan bahwa pengelolaan yang dilakukan oleh pemerintah sebagai pengelola tunggal kawasan Pasar Terapung Kuin dan Siring dalam menjalankan visi dan misi serta mewujudkan tujuan yang ditetapkan adalah dengan menghadirkan kawasan pasar terapung yang mudah diakses oleh pengunjung dan wisatawan yaitu Pasar Terapung Siring. Tetapi dengan adanya pasar terapung tersebut, tentunya akan memberikan dampak yang kurang baik terhadap pasar terapung tradisional jika tidak diimbangi dengan sistem pengelolaan yang sama. Pemerintah banyak melakukan program pengembangan dan pemeliharaan terhadap kawasan Pasar Terapung Siring tetapi perlakuan tersebut tidak banyak dilakukan terhadap kawasan Kuin. Dari segi kebutuhan penunjang pariwisata seperti ketersediaan fasilitas umum dan fasilitas pariwisata tidak berjalan serentak, yang artinya peningkatan fasilitas paling tinggi hanya terdapat di wilayah Pasar Terapung Siring dan tidak terjadi di Pasar Terapung Kuin. Peran serta masyarakat sekitar kawasan wisatapun dapat dikatakan tidak berjalan beriring. Masyarakat di kawasan Pasar Terapung Siring terindikasi sudah sadar akan potensi wisata yang ada yang dapat memberikan dampak peningkatan ekonomi terhadap keterlibatannya dalam kepengurusan. Sedangkan untuk warga masyarakat Kuin, seperti belum adanya organisasi yang secara resmi menaungi pengelolaan kawasan dapat dikatakan bahwa belum terjadi kesadaran di masyarakat akan potensi pariwisata yang dimiliki. Sementara berbagai faktor ancaman mulai hadir seiring pesatnya perkembangan industri pariwisata dewasa ini. Apabila peran serta masyarakat tidak terbangun dengan baik maka keberlanjutan dari kawasan Pasar Terapung Kuin dipastikan akan menghilang dan punah. Belum lagi masalah regenerasi komponen Pasar Terapung Kuin yang apabila tidak ada sistem daur hidupnya maka akan terjadi berbagai ancaman yang dikhawatirkan selama ini. Sehingga disini perlu adanya peran yang saling memberikan timbal balik antara pemerintah setempat dan warga masyarakat lokal. Peran pemerintah sebagai pengelola pun haruslah mampu mengatasi dan menangani permasalahan yang ada di masyarakat tersebut. Sentuhan stimulasi oleh pemerintah haruslah mampu menembus masuk ke lapisan masyarakat hingga akar, tidak hanya menyentuh permukaan sebagai salah satu komponen dalam pengembangan yang dilakukan.

\section{Kepustakaan}

AdarshBatra. 2014. Jurnal Floating Markets: Balancing the Needs of Visitors as a Tourist Attraction and Locals Way of Life. A Case Study of Talingchan Floating Market, Bangkok Thailand. World Applied Sciences Journal 30 (Innovation Challenges in Multidiciplinary Research \& Practice): 332-343.

Allison, Michael dan Jude Kaye. Perencanaan Strategis bagi Organisasi Nirlaba: Pedoman Praktis dan Buku Kerja. Jakarta: Yayasan Pustaka Obor Indonesia. 
Assauri, Sofjan. 2016. Strategic Management; Suistainable Competitive Advantages. Jakarta: Rajawali Pers.

Badan Penelitian dan Pengembanagn Kalimantan Selatan. 2003.

Budiarta, K., \& Thamrin, Z. 2013. Kajian tentang industri kreatif sebagai pengembangan UMKM unggulan Kota Medan. Jurnal Pembangunan Kota, 1(1), 1- 30.

Dalrymple, Douglas J. \& Leonard J. Parsons. 2000. Basic Marketing Management, Second Edition. New York: John Wiley \& Sons.

Departemen Perdagangan Republik Indonesia. 2008. Pengembangan Ekonomi Kreatif Indonesia 2025: Rencana Pengembangan Ekonomi Kreatif 2009-2015. Retrieved from Jakarta:

Dwi Susanti, I. A. M., Darmawan, Dwi Putra., Astiti, N. W. Sri. 2014. Strategi Pengembangan Pasar tradisional Kertha, Desa Kesiman Kertalangu, Kecamatan Denpasar Timur. Jurnal Manajemen Agribisnis 2(1) 11-21.

Eriyanto. 2015. Analisis Isi; Pengantar Metodologi untuk Penelitian Ilmu Komunikasi dan Ilmu-ilmu Sosial Lainnya. Jakarta: Prenadamedia Group.

I Putu Gede Sukaatmadja, Ni Nyoman Kerti Yasa, Henny Rahyuda, I.G.A. Ngr. Jaya Widagda. 2014. Strategi pengembangan pasar tradisional berbasis kearifan lokal untuk mengentaskan kemiskinan di Bali. Jurnal Manajemen; Strategi Bisnis dan Kewirausahaan 8(2) 121-129.

Kartajaya, Hermawan dan Sapta Nirwandar. 2013. Tourismn Marketing 3.0: Turning Tourist to Advocate. Jakarta: PT. Gramedia.

Kartini La Ode Unga, I Made Benyamin dan Roland Alexander Barkey. 2011. Strategi Pengembangan Kawasan Wisata Kepulauan Banda.

Damayanti, Maya, Latifah. 2015. Strategi Kota Pekalongan dalam Pengembangan Wisata Kreatif Berbasis Industri Batik. Jurnal Pengembangan Kota 3(2), 100-111.

Nawawi, Hadari. 2012. Manajemen Strategik Organisasi Nonprofit Bidang Pemerintahan. Yogyakarta: Gadjah Mada University Press.

Neuman, W. Lawrence. 2013. Metodologi Penelitian Sosial: Pendekatan Kualitatif dan Kuantitatif. Jakarta: Indek Permata Puri Media.

Nirwandar, Sapta. 2014. Building Wow: Indonesia Tourism and Creative Industry. Jakarta: PT. Gramedia.

Ohridska-Olson, R., \& Ivanov, S. (2010, September 24). Creative tourism business model and its application in Bul- garia. Proceedings of the Black Sea Tourism Forum "Cultural Tourism - the Future of Bulgaria", Varna.

Priyatmono, Alpha Febela. 2012. Pengembangan Pariwisata Kreatif Berbasis Komunitas Dan Budaya Lokal, (Studi Kasus Kampung Perhiasan Njayengan Surakarta). Simposium Nasional Xi FT UMS 18-24.

Primadany, Sefira Ryalita., Mardiyono, Riyanto, 20xx. Analisis strategi pengembangan pariwisata daerah (Studi pada Dinas Kebudayaan dan Pariwisata Daerah Kabupaten Nganjuk). Jurnal Administrasi Publik 1(4) 135-143.

Rangkuti, Freddy. 2015. Analisis SWOT: Teknik Membedah Kasus Bisnis. Jakarta: PT. Gramedia Pustaka Utama.

Sejarah Banjar. 2003. Badan Penelitian dan Pengembangan Daerah Provinsi Kalimantan Selatan.

Solihin, Ismail. 2004. Pengantar Manajemen. Jakarta: Erlangga.

Sobur, Alex. 2003. Psikologi umum. Bandung: Pustaka Setia.

Tan, S. K., Luh, D. B., \& Kung, S. F. 2014. A Taxonomy of Creative Tourists in Creative Tourism. Tourism Management, 42(0), 248-259.

Utama, I Bagus Rai \& Mahadewi, Ni Made Eka. 2012. Metode Penelitian pariwisata \& Perhotelan. Yogyakarta: Andi Offset. 
Wattanacharoensil, Walanchalee, Malinvisa Sakdiyakorn. 2015. The Potential of Floating Markets for Creative Tourism: A Study in Nakhon Pathom Province, Thailand. Asian Pasific Journal of Tourism Research.

Widadio, N. A. (2014, 02 April). Menparekraf: Perkembangan Pariwisata Indonesia Paling Bagus. Kompas. Retrieved from http://travel.kompas.com/read/2014/04/02/0 949478/Menparekraf.Perkembangan.Pariwisat a.Indonesia.Paling.Bagus

Yoeti, Okta A. 2016. Perencanaan dan Pengembanagan Pariwisata. Jakarta: PT. Balai Pustaka.

\section{Sumber Internet}

https://banjarmasinkota.bps.go.id/

http://bappeda.kalselprov.go.id

http://www.bppaudnibanjarbaru.org

www.hukumonline.com

pedagangpasar.org

www.share.its.ac.id 